\title{
THE PROGRESS OF ISLAMIC BOARDING SCHOOL IN DEVELOPING STUDENT MORALS (CASE STUDY IN ISLAMIC BOARDING SCHOOL OF DARUL ABRAR, BONE)
}

\author{
Nur Apriyani ${ }^{1}$ \\ Muljono Damopolii ${ }^{2}$ \\ Hamzah Harun Al-Rasyid ${ }^{3}$ \\ Post Graduate Program of Alauddin State Islamic University Makassar, Indonesia ${ }^{1}$ \\ Lecture at The Faculty of Tarbiyah and Teacher Training Alauddin State Islamic \\ University Makassar, Indonesia ${ }^{2,3}$ \\ nurapriyani2404@gmail.com ${ }^{1}$, muljono.damopolii@uin-alauddin.ac.id ${ }^{2}$, \\ hamzah.harun@uin-alauddin.ac.id ${ }^{3}$
}

\begin{abstract}
Islamic boarding school is one of Islamic educational institution that plays an active role in the formation of human noble morals. Specifically in the development and fostering of student morals in order to form virtuous souls and understand Islamic values well. The Islamic Boarding School of Darul Abrar also plays a role in fostering the morals and mentality of the students, like boarding schools in general and also has a vision and mission to be achieved, one of which is become a person who a morality, this is in line with the ultimate goal of life. This study aims to determine the variety of morals efforts to foster student at the Islamic Boarding School of Darul Abrar, Bone. The research methodology in this study is qualitative, and the data collection techniques using observation, interviews and documentation. The results of this study indicate that efforts to develop moral character of female students can be done by increasing the reading of the Qur'an, applying disciplinary methods of discipline, applying the valuesof the five souls that are a reference to the boarding school, conducting through learning and moral guidance through extracurricular activities.
\end{abstract}

Keywords: Islamic Boarding School; Morals; Student

\section{INTRODUCTION}

Islamic boarding school as religious institution are rooted in the community and has become a part of sociocultural community, schools also have opportunities in economic mobilization. ${ }^{1}$ Islamic boarding school is an Islamic educational institution that was instrumental in the development and moral development of students, in order to form a virtuous life and understand the value of Islam especially those in interacting with humans, the surrounding nature, and the creator.

According Dhofier, educational institutions consist of student boarding schools, mosques, preachers, and the lodge as the residence of the students. Dhofier, dividing split to two types, ie there are salaf and khalaf. Islamic boarding school of

${ }^{1}$ Hamzah Harun al-Rashid, Pesantren dan Studi Islam (Cet. I; Yogyakarta: Panrita Global Media, 2015), p. 1. 
Salaf embrace education system that is traditional teaching is still shaped halaqah, wetonan, faculty is very limited and the learning material taken from a book just like the book of al-Nasäih al-Dïnìyah, Tafsìr al-Jalālain, and other. While, Islamic boarding school of Khalaf embrace education system that is classical, there are levels in each stage of learning, as well as an evaluation for a class rise, many lecturers, there are holding classes and some teachers of certain subjects, as well as learning material consists of several types of books. ${ }^{2}$

In general, developing schools as a teacher of Islam as the leader of the struggle, which pesantren itself aims to teach the students, fosteringmoral, nourish the spirit, mutual respect, and teach the meaning of simplicity. Thus the reciprocation of a country can be seen from the generation of learners, for learners is the success of a nation. Therefore, development of character in a generation is very important, so that the state and religion do not deteriorate over time. Because with a good moral to create a noble character. As word as of God in Al-Ahzāb/33: 21.

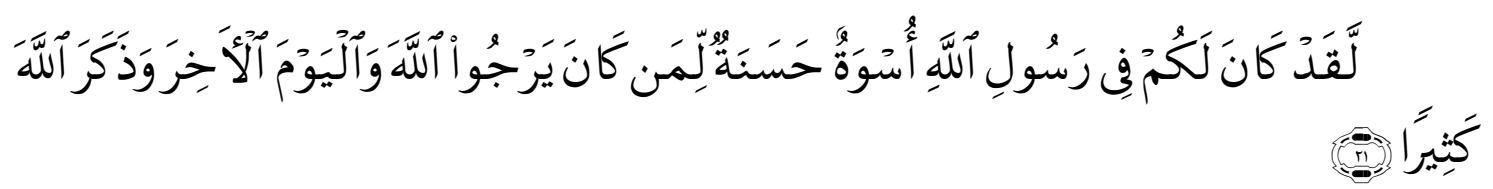

Translation:

"Indeed, there has been the (self) that the Messenger of Allah a good role model for you (that) for people who expect (grace) of God and the (arrival) Day of Judgment and that many remember God."3

Speaking of moral guidance, closely related to the formation and development of Islamic objectives. Therefore, many experts argue that the purpose of fostering equal to the formation of character.In this case the manners and morals of coaching is the goal of Islamic guidance.

Moral comes from the word meaning khalaqa create, making, being, ${ }^{4}$ and khuluq is basically a word which means manners, character or behavior. In the Qur'an the word character was not found, but he returned to the single word that is khuluq, and these words convey the same morals. In Surah al-Qalam/68: 4, Allah says:

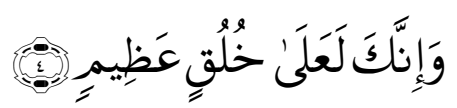

Translation:

"And actually you are really virtuous noble character."

The second based on the verse, it is clear that good character is something noble and highly commendable. Thus the character must always be maintained, so that each individual consciousness, and act wisely, selfless, and establish it self as the spearhead of the nation's success.

In education, morality has a very good purpose, which is to improve the quality of a person in order to achieve a complete character, integrated and balanced. With the

\footnotetext{
${ }^{2}$ Indra Hasbi, Pesantren dan Transformasi Sosial Studi atas Pemikiran K.H Abdullah Syafi'ie dalam Bidang Pendidikan Islam (Cet. II; Jakarta: Penamdani, 2005), p. 218

${ }^{3}$ Departemen Agama RI, Al-Qur'an dan Terjemahnya (Jakarta: Darus Sunnah, 2007), p. 421.

${ }^{4}$ Zainuddin Ali, Pendidikan Agama Islam (Cet. II; Jakarta: Bumi Aksara, 2008), p. 3.

${ }^{5}$ Departemen Agama RI, Al-Qur'an dan Terjemahnya, p. 565.
} 
existence of this moral education, the students are expected to be independent and use common sense in assessing and positioning the noble moral values in their daily lives.

The education and development of intelligence that a character can form students, both in terms of intellectual, emotional, social, and spiritual. Which intelligence is the ability of students to develop their intellectual, so that it is capable of rational thinking, creative and able to cope with its problems it self. While emotional intelligence intended that student be able to restore him self in any situation, so that he is able to stand alone, strong in the face of various challenges. Social intelligence, all of students can live and interract with the surrounding nature. And spiritual intelligence where students are able to live a religious value and apply it in daily life. Fourth this intelligence is the provision in achieving success. ${ }^{6}$

Thus the character is the spirit of a person, because it is a characteristic that appears and as a differentiator among others. And is promoting moral religion is Islam, the hadis it is said:

$$
\begin{aligned}
& \text { حدثنا أحمد بن حنبل حدثنا يحيى بن سعيد عن محمد بن عمرو عن أبي سلمة عن أبي } \\
& \text { هريرة قال قال رسول الله صلهى الله عليه وسلم أكمل المؤمنين إيمانا أحسنهم خلقا }
\end{aligned}
$$

This means:

"From Ahmad bin Hanbal said, from Yahya bin Sa'id from Muhammad ibn Amr, from Abu Salamah from Abu Hurayrah he said, "The Prophet Muhammad said: The best of the faithful is the most good faith depraved."

Hadis above explained that the goodness of a person's faith will be apparent from its character (in this case not only to God, but other creatures).

Based on the above, this research will discuss about The Gait of Islamic Boarding School in Developing Student Morals (Case Study in Islamic Education Boarding School of Darul Abrar, Bone). The purpose of this study was to determine the student morals wide development efforts in Islamic Boarding School of Darul Abrar, Bone.

\section{LITERATURE REVIEW}

\section{A. Islamic Boarding School}

\section{Definition of Islamic Boarding School}

The word "pesantren" comes from the word is "santri", with the addition of the prefix "pe" and the suffix "an" which means the abode of the students. ${ }^{7}$ While the term students according to Professor Johns, as quoted Damopolii derived from the Tamil word meaning tutor, and by CC Berg, student coming from said Shastri, in the Indian language means one who knows about the sacred books of Hinduism. ${ }^{8}$

${ }^{6}$ Aisha M. Ali, Pendidikan Karakter Konsep dan Implementasinya (Jakarta: Prenadamedia Group, 2018), p. 13-14.

${ }^{7}$ Zamakhsyari Dhofier, Tradisi Pesantren: Studi Tentang Pandangan Hidup Kyai (Cet. VI; Jakarta: LP3ES, 1994), p. 18.

${ }^{8}$ Muljono Damopolii, Pesantren Modern IMMIM Pencetak Muslim Modern (Jakarta: Rajawali Pers, 2011), p. 56. 
There is also another term that is often juxtaposed with boarding school said that the cottage, which is known in the community "pesantren". Dhofier found the lodge said it was the residence of the students made of bamboo or absorbed from the Arabic word meaning funduq is hotel or hostel. ${ }^{9}$ While the terminology, boarding interpreted as the traditional Islamic educational institutions, in which the students learn, understand, explore, appreciate and practice the teachings of Islam by making religious morals as a guide in their daily behavior. ${ }^{10}$ Currently the schools have become the education institutions follow the national education system, so not only synonymous with Islamic values but also understand the significance of Indonesia. As schools which have existed for hundreds of years, until Islam went on to convert the existing educational institutions. ${ }^{11}$

Boarding school can stand up for the fight kiai and his students and with the help of the local community, thus schools have different characteristics and for the national somewhat difficult, so that schools have specific characteristics depending on the kiai, culture, and geography. ${ }^{12}$ By seeing the differences in habits or morals of the students themselves, the builder with all efforts tries to grow the morale of students toward better. This is the biggest challenge for coaches and teachers in the face of all the shortcomings, chaos, and the difference of the students in order to form a better character. Due to the background of each of the students will affect the pattern of coaching students, whether from differences in language, customs, culture or their reasons for entering boarding school.

\section{Interest of Boarding School}

The purpose of schools is generally to foster citizens in order to create Muslim personality in accordance with the guidance of Islamic religion and religious embed be able to become a useful person for religion, society and the state. ${ }^{13}$ While the special purpose schools are:

a. Educating students become Muslim always have fear of Allah, has a noble spirit, intelligent, skilled and healthy physically and mentally as citizens five precepts.

b. Educating students to be a cadre of scholars and preachers, spirited sincere, steadfast, strong and dynamic practice of Islamic history.

c. Educating students being personally responsible for the development of the nation and the state.

d. Educating families and communities.

e. Educating students being personally reliable in mental-spiritual development.

f. Educating students to be able to improve social welfare.

\footnotetext{
${ }^{9}$ Muljono Damopolii, Pesantren Modern IMMIM Pencetak Muslim Modern, p. 56-57.

${ }^{10}$ Mastuhu, Dinamika Sistem Pendidikan Pesantren: Suatu Kajian tentang Unsur dan Nilai Sistem Pendidikan Pesantren (Jakarta: INIS, 1994), p. 55.

${ }^{11}$ Nurcholish Madjid, Bilik-Bilik Pesantren: Sebuah Potret Perjalanan (Jakarta: Dian Rakyat, 1997), p. 5.

${ }^{12}$ Mujamil Qomar, Pesantren: dari Transformasi Metodologi Menuju Demokratisasi Institusi (Jakarta: Erlangga, 2005), p. 16.

${ }^{13}$ Mujamil Qomar, Pesantren: dari Transformasi Metodologi menuju Demokratisasi Institusi, p. 6.
} 
By looking at some of pesantren above, we conclude boarding goal is to establish an individual Muslim who is able to master, understand and practice the teachings of Islam in order to be able to bring benefits to religion, society and the state.

\section{Elements of Boarding School}

Zamakhsyari Dhofier boarding mapped elements into five parts, namely: the cottage/pondok, mosques, teaching the classics, students and kiai.

\section{a. Cottage (Pondok)}

Cottage has historically been a symbol of humility, which is used as a place to stay for students because of the distance between students and scholars who were previously made of bamboo. The term "cottage/pondok" is derived from the Arabic is funduq which mean a great place to stay normal in use as a haven. With the existence of this cottage, religious leaders easily oversee the activities carried out by the students.

\section{b. Mosques}

The mosque is also used to train student skills such as prayer, lectures, azan, taking care of the mosque and others. The membership is very beneficial for the students, both when he was still a plunge in students as well as society.

\section{c. Teaching Classic's Islam Book}

As for the classic were taught as naḥwu dan șaraf, fiqh dan usul fiqh, hadis, tafsir, tauhīd, tasāwuf and books volumes thick, the overall grouped into three books of basic books, medium books and tomes. ${ }^{14}$ To be able to translate and understand the contents of the book and then the students should master grammar Arabic called balāgah as well as other branches of religious knowledge.

\section{d. Santri}

Santri are studying in boarding schools. There are two kinds of students, mukim students and students did not stay. Mukim are students who come from remote areas and want to settle in schools. While students did not stay are students who come from the villages around schools, so that they can easily learn at the school and then return home after studying. ${ }^{15}$

\section{e. Kiai}

Kiai within the scope of boarding a single leader who holds authority over all decisions, as well as into the back of the students and become the most respected and appreciated, therefore kiai the cast as well as a protector for the students. ${ }^{16}$. The

\footnotetext{
${ }^{14}$ Amien Haedari et al, Masa Depan Pesantren dalam Tantangan Modernitas dan Tantangan Kompleksitas Global, (Jakarta: IRD Press, 2004), p. 40.

${ }^{15}$ Amien Haedari et al, Masa Depan Pesantren dalam Tantangan Modernitas dan Tantangan Kompleksitas Global, p. 35.

${ }^{16}$ Mujamil Qomar, Pesantren: dari Transformasi Metodologi menuju Demokratisasi Institusi, p. 31.
} 
quality and effect of the kiai depends on progress and setbacks. The ability of the figure Kiai is at stake in producing students who 'alim and charismatic. However, there are things that differ from those Dhofier about the elements of the boarding school, the Islamic Boarding School of Darul Abrar, Bone where researchers conducted the study, there are things that really attracted the attention of researchers, on the campus of self that skill activities undertaken by the students such as farming, gardening, farming and other activities for students who do not pay and wants to be more independent.

\section{B. Development of Morals}

Coaching is an activity carried out consciously to achieve the perfection of what you have, both in terms of knowledge and skills. In human life, morality can not be separated from religious beliefs. Because of the strict moral values, fixed and definite that it can not change even if something happens to the place and time for overall all derive from religion. Therefore, in the formation of a strong religious morality, it is necessary because both will go hand in hand.

\section{Akhlak}

Virtue is an attitude and behavior that lead to acts spontaneously without any consideration first. ${ }^{17}$ Virtue is more to everything that comes from the Qur'an and Hadis. In the terminology, the notion of morality associated with three elements, namely: a) Cognitive, namely as a basic knowledge of a person based on their intellectual potential. b) Affective, namely the development of the potential of the sense someone based on how they analyze the various sciences. c) Psychomotor, namely the rational understanding towards concrete actions. ${ }^{18}$

The researchers concluded that morality is the urge to perform an act of pure comes from the soul, and will appear instantly without considering beforehand, whether it is the encouragement of character, a mind or conscience. Behavior can be measured through behavior that is often repeated or habitual someone in his life, both within the school, home and in society, because it is a trait that has been ingrained in him, and will appear without thought or other considerations.

The factors that influence the formation of a person's character, namely:

\section{a. Internal factors}

Internal factors are factors of birth of the individual, this factor is genetic, meaning of that there is a factor since he was born and brought habits of their off spring or parents.

\footnotetext{
${ }^{17}$ Mahmud Syujuthi, Catatan Kecil Seorang Da'I dan Nasehat Sampai Syafaat (Cet. I, Surabaya: Al-Ihsan, 1995), p. 109.

${ }^{18}$ Beni Hamid and Ahmad Hamdani Saebani, Pendidikan Karakter Perspektif Islam (Cet. I; Bandung: Pustaka Setia, 2013), p. 44.
} 


\section{b. External factors}

This external factor is a factor which exists outside of oneself, that is the influence that comes from the surrounding environment or the influence of family, friends, or influence brought about by the media.

According jumhur, good character exemplifies the nature of the Prophet, and the nature of the upright, while the bad character is a trait that is exemplified by a vicious and despicable person. Therefore, morality categorized into two parts, namely:

\section{a. Good manners}

Moralsgood or often called akhlāk al-mahmudah that all aspects of human life in the form of good works contained in a person, a good relationship with Allah as well as closely related to humans and other creatures. Among the commendable morals: ${ }^{19}$

1) Diligent is a commendable act, both diligent in terms in terms of worship and in daily life.

2) Thorough is the attitude expected in every respect for what is done, so as not to be mistaken in working and making decisions.

3) Patience in the face of all the issues, problems in interacting with Allah, nor creature creations

4) Honest in all things, both word and deed.

5) Sincerely is an act that only would please Allah.

6) Forgiving is an attitude that is favored by Allah and other human beings, and still banyk other laudable trait that can be used as examples in everyday life.

b. Morals Reprehensible

Akhlak al-madzmumah that all things bad, bad for Allah, humans and other creatures. As; often lie, do dzalim, being takabbur, despair, and cowardice. ${ }^{20}$ Akhlak will appear based on the self and the environment, when genetically he is a good influence and the environment is also positive it will form a private air morals, other wise if not then it will be a personal form that does not have good morals.

2. Moral Development Methods

Here are some methods that can be applied in coaching morals, namely:

a. Nature monologue lecture method, can be used to convey information.

b. Exemplary method of providing concrete examples to the students by example (uswatun hasanah) both of Kiai, the coach / teachers and the senior students both in worship and in terms of other virtues.

\footnotetext{
${ }^{19}$ Nur Khalisah Latuconsinah, Aqidah Akhlak Kontemporer (Cet: I; Makassar: Alauddin University Press, 2014), p. 129.

${ }^{20}$ Didiek Ahmadi Supardie, Pengantar Studi Islam (Cet. I; Jakarta: Raja Grafindo Persada, 2011), p. 226.
} 
c. Habituation method is the method of implementation with training on values/norms with the intention of the students can get used to doing things that are positive, as in the case of worship, polite behavior and commendable to kiai and teachers as well as to other students.

d. Discipline methods to make students become aware of something wrong he had done so he would not do it again.

e. The method is intended that the independence of the students were able to give a decision on a case, both monumental and decisions on things that are everyday life. ${ }^{21}$ Thus the students are able and more likely to make a decision.

\section{Importance of Moral Guidance}

Achieve closeness to Allah, people are urged to always be in a state of purity and sincere worship that is done will make man a slave strong and clean soul will take someone to good manners. ${ }^{22}$ Religion in human life is something that is needed, because religion is a guide in all things, especially in spiritual matters. As for the rules of religion are the highest points for each individual, from where can be seen the extent to which obedience a servant to his God. And the religious norms in use as the rule of law that comes from Allah, actually just to make someone to be perfect man, as well as in coaching behavior.

Worship can foster spiritual, attitude and character of a person. Therefore, morality is closely associated with worship. Someone who often serve either worship in the form of words or deeds, whether mandatory or sunnah will shine of her attitude and good character, because his guidance of worship that has been done will appear by itself, so someone will awake from the actions reprehensible. Allah gives an example in Surah Ibrāhim/14: 26, which read:

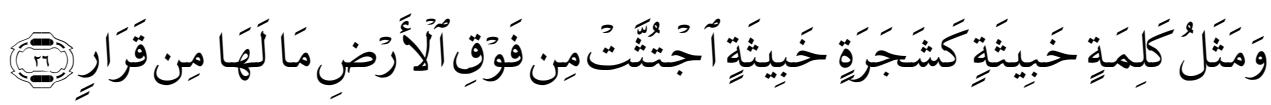

Translation:

"And the parable of a bad sentences like a bad tree, which has been lifted by the roots from the earth's surface; can not be fixed (upright) bit." 23

The above verse describes how meruginya someone who often put out bad words, so God emphatically warned. Therefore, not only the action that must be fostered and maintained in order to better reflect a person's character, but the words are also included in the case to be constantly maintained and familiarized to keep control.

Thus, the morals of Islam serves as a filter to select the character that is, within the meaning of morality appropriate and not contrary to Islamic values is allowed to grow continuously, so that its use does not deviate from the purpose of the religion of Islam that can nourish the soul, mind, wealth, lineage and religion.

${ }^{21}$ Abd. Rahman and Nahlawi, Prinsip-prinsip dan Metode Pendidikan Islam diterjemahkan oleh Dahlan dan Sulaiman, (Bandung; Diponegoro, 1992), p. 415.

${ }^{22}$ Syahidin, et al, Moral dan Kognisi Islam (Cet. III; Bandung: Alfa Beta, 2009), p. 244.

${ }^{23}$ Departemen Agama RI. Al-Qur'an dan Terjemahnya, p. 260. 


\section{RESEARCH METHOD}

This study classified is field research and this includes qualitative research. Qualitative research is research that gives an overview of the situation and phenomena that occur in the study site in accordance with the natural conditions of the research object. $^{24}$ Technical analysis of the data used is data reduction, data presentation, and verification.

\section{IV.RESULT AND DISCUSSION}

Patrons Islamic Boarding School of Darul Abrar, Bone in fostering his students always pay attention to the potential and talents of the students, because students are the trust that must be nurtured and directed. Coaches wanted his students are able to understand and practice the knowledge possessed especially religious knowledge, is able to understand the meaning of sincerity, simplicity, establish brotherhood Islamiyah, self-sufficient and capable of enforcing discipline. Islamic Boarding School of Darul Abrar expects the students were able to memorize and study the Quran, and studied the whole lesson well. The efforts made in the formation of character santriwati as follows:

\section{A. Multiply Reciting Quran} Qur'an:

As stated by the coach pesantren daughter about the virtues examine the

"Qur' an capable of providing light to anyone who reads it, especially on those who study it, therefore, the boarding combines Qur'an recitation with education, with the intention that the students studying in memorizing and learning facilitated and people who take care of the Qur'an will be guarded by Allah, especially faith and moral and Qur'an also been instrumental in the hereafter." 25

Results of these interviews can the researcher understand that by reading and studying the Qur'an, one would be more purposeful life, the knowledge gained can be more easily understood, and behavior and morals will be controlled, because the Qur' an is a sedative, the giver of light and can give intercession to its readers.

\section{B. Applying the method of discipline rules}

Islamic Boarding School of Darul Abrar has rules that must be obeyed all students. Development pattern with this method was able to change bad habits for the better so as to guide female students will be easier. As the opinion of ustazah on interview;

"Enforcement of discipline must be done, so that the development and character formation of female students will be lead to something positive.

\footnotetext{
${ }^{24}$ Sayuti M. Ali, Metodologi Penelitian Agama Pendekatan Teori dan Praktek (Cet. I; Jakarta: RajaGrafindo Persada, 2009), p. 59.

${ }^{25}$ Andi Sitti Nurhasanah Cinnong (76 years), Trustees of Islamic Boarding School of Darul Abrar, Interview, Balle, 29 November 2019.
} 
Although there is a bit of female students who often commit the offense, but the impact of this discipline will have an effect for themselves, for the present and future." ${ }^{26}$

Enforcement of discipline is to be implemented, both in regulating the daily students or learning, because of the growth of a person will rely on custom patterned on him, thus in the process of growth and development of female students they will be better able to understand, appreciate, and be able to practice his duty as a santriwati to a disciplined life in order to reach success.

\section{Applying the value of the five souls}

Each institution has a core value, and its own characteristics, as well as with Islamic Boarding School of Darul Abrar. In these schools, there are five senses souls who want to apply to the soul santriwati, namely: sincerity, simplicity, brotherhood Islamiyah, self-reliant, and disciplined.

The fifth of the five souls possessed Islamic Boarding School Darul Abrar is the spirit which can determine the reciprocation of boarding school. In accordance with the statement Hj. A. Sitti Nurhasanah Cinnong:

"This Islamic Education Boarding School Darul Abrar have five souls cottage to be instilled in the soul santriwati is sincerity, simplicity, brotherhood Islamiyah, self-reliant, and disciplined. All the female students have and being able to practice the five souls, then spirit and morals santriwati boarding and ustazah would be better." 27

The statement was reinforced by the statement Andi Faridah S, S.Pd:

"If the moral guidance berasaskan five people then that all the activities carried out in this pesantren best be achieved, as well as the formation of the female students will be directed character and will not be easily affected by the negative things, and creativity and potential of female students will be more developed." 28

Based on interviews of researchers, it can be seen that if the value of the soul senses applied in Islamic Boarding School of Darul Abrar in line with the teachings of Islam, al-Qur'an and hadis the development and character of the female students can go to positive things, either while still in boarding schools or when the female students to mingle with other people.

\section{Coaching character through learning}

Islamic Education Boarding School Darul Abrar which have five souls in the form of sincerity, simplicity, brotherhood Islamiyah, self-reliant, and disciplined,

\footnotetext{
${ }^{26}$ Andi Nurghaziah (27 years), Teacher of Islamic Boarding School of Darul Abrar, Interview, Balle, 7 December 2019.

${ }^{27}$ Andi Sitti Nurhasanah Cinnong (76 years), Trustees of Islamic Boarding School of Darul Abrar, Interview, Balle, 29 November 2019.

${ }^{28}$ Andi Faridah S (30 years), Teacher of Islamic Boarding School of Darul Abrar, Interview, Balle, December 28, 2019.
} 
applying the five scores on learning, thus forming a moral value, which is integrated with all subjects that have been adapted to the existing curriculum.

Not only in the classroom, but there is also an extra hour in the evening for female students who do not understand or who want a more detailed explanation can be joined to the guidance which is held by teachers and this is also a form of guidance akhlak through a learning process.

\section{E. Coaching character through extracurricular activities}

Their extracurricular activities in Islamic Boarding School of Darul Abrar has meant for the female students able to support themselves and manage such leadership in the organization. Because this extracurricular are considering support for the growth of female students outside of class. In this extracurricular activity, it also contains the value of that character students five souls can reflect an exemplary attitude, as well as observations of researchers.

\section{CONCLUSION}

The variety of moral development efforts students in Islamic Education Boarding School Darul Abrar Bone Regency, as follows:

a. Multiply reciting the Quran

b. Applying the method of discipline rules

c. Applying the value of the five souls

d. Coaching character through learning

e. Coaching character through extracurricular activities

\section{REFERENCE}

Ali, Aisyah M. Pendidikan Karakter Konsep dan Implementasinya. Jakarta: Prenadamedia Group, 2018

Ali, M. Sayuti Metodologi Penelitian Agama Pendekatan Teori dan Praktek. Cet. I; Jakarta: RajaGrafindo Persada, 2009.

Ali, Zainuddin. Pendidikan Agama Islam. Cet.II; Jakarta: Bumi Aksara, 2008.

Al-Rasyid, Hamzah Harun, Pesantren dan Studi Islam. Cet. I; Yogyakarta: Panrita Global Media, 2015.

Damopolii, Muljono. Pesantren Modern IMMIM Pencetak Muslim Modern. Jakarta: Rajawali Pers, 2011.

Departemen Agama RI, Al-Qur'an dan Terjemahnya. Jakarta: Darus Sunnah, 2007.

Dhofier, Zamakhsyari. Tradisi Pesantren: Studi Tentang Pandangan Hidup Kyai. Cet. 
VI; Jakarta: LP3ES, 1994.

Hamid, Hamdani dan Beni Ahmad Saebani. Pendidikan Karakter Perspektif Islam. Cet. I; Bandung: Pustaka Setia, 2013.

Haedari, Amien dkk. Masa Depan Pesantren dalam tantangan Modernitas dan Tantangan Kompleksitas Global. Jakarta: IRD Press, 2004.

Latuconsinah, Nur Khalisah. Aqidah Akhlak Kontemporer. Cet: I; Makassar: Alauddin University Press, 2014.

Madjid, Nurcholish. Bilik-Bilik Pesantren: Sebuah Potret Perjalanan. Jakarta: Dian Rakyat, 1997.

Mastuhu, Dinamika Sistem Pendidikan Pesantren: Suatu Kajian tentang Unsur dan Nilai Sistem Pendidikan Pesantren. Jakarta: INIS, 1994.

Qomar, Mujamil. Pesantren: dari Transformasi Metodologi menuju Demokratisasi Institusi. Jakarta: Erlangga, 2005.

Rahman, Abd. dan Nahlawi. Prinsip-Prinsip dan Metode Pendidikan Islam diterjemahkan oleh Dahlan dan Sulaiman. Bandung: Diponegoro, 1992

Supardie, Didiek Ahmadi. Pengantar Studi Islam. Cet. I; Jakarta: Raja Grafindo Persada, 2011.

Syahidin, dkk, Moral dan Kognisi Islam. Cet. III; Bandung: Alfa Beta, 2009.

Syujuthi, Mahmud. Catatan Kecil Seorang Da'I dan Nasehat Sampai Syafaat. Cet. I, Surabaya: Al-Ihsan, 1995. 